Key Words:

Vadose Zone

PORFLOW

Performance Assessment

Retention:

Permanent

\title{
An Evaluation of Aquifer Source Node Location Alternatives for E-Area Slit Trench Performance Assessment
}

Prepared by:

Gregory P. Flach

Leonard B. Collard

March 28, 2003

Rev. 0

Westinghouse Savannah River Company

Savannah River Site

Aiken, SC 29808

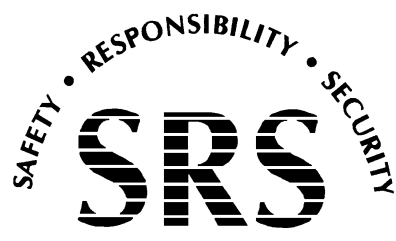

SAVANNAH RIVER SITE

Prepared for the U.S. Department of Energy Under

Contract Number DE-AC09-96SR18500 
This document was prepared in conjunction with work accomplished under Contract No. DE-AC09-96SR18500 with the U. S. Department of Energy.

\section{DISCLAIMER}

This report was prepared as an account of work sponsored by an agency of the United States Government. Neither the United States Government nor any agency thereof, nor any of their employees, makes any warranty, express or implied, or assumes any legal liability or responsibility for the accuracy, completeness, or usefulness of any information, apparatus, product or process disclosed, or represents that its use would not infringe privately owned rights. Reference herein to any specific commercial product, process or service by trade name, trademark, manufacturer, or otherwise does not necessarily constitute or imply its endorsement, recommendation, or favoring by the United States Government or any agency thereof. The views and opinions of authors expressed herein do not necessarily state or reflect those of the United States Government or any agency thereof.

This report has been reproduced directly from the best available copy.

Available for sale to the public, in paper, from: U.S. Department of Commerce, National Technical Information Service, 5285 Port Royal Road, Springfield, VA 22161, phone: (800) 553-6847, fax: (703) 605-6900

email: orders@ntis.fedworld.gov

online ordering: http://www.ntis.gov/help/index.asp

Available electronically at http://www.osti.gov/bridge

Available for a processing fee to U.S. Department of Energy and its contractors, in paper, from: U.S. Department of Energy, Office of Scientific and Technical Information, P.O. Box 62, Oak Ridge, TN 37831-0062,

phone: (865)576-8401,

fax: (865)576-5728

email: $\underline{\text { reports@ adonis.osti.gov }}$ 


\section{Executive Summary}

A recent "Point Source" Special Study focusing on the potential impacts of non-uniform waste distribution in the E-Area Slit Trenches indicates that alternative strategies for defining aquifer source node locations may significantly affect the peak concentration observed at the 100 meter well in the Upper Three Runs aquifer. To enable accurate representation of point sources and corresponding downstream effects in the Special Study, a re-oriented and finer resolution computational mesh was used to simulate aquifer flow and transport. When a uniform waste distribution was modeled as a precursor to various hypothetical point source scenarios, peak concentrations at the 100 meter well were on the order of 2 times higher than reported in the Performance Assessment (PA) for I-129. A preliminary assessment suggested that differences in peak concentrations between the Special Study and PA models were primarily due to differences in aquifer model source node locations, as opposed to mesh resolution and orientation.

Aquifer source nodes define the computational cells that receive the contaminant flux predicted to enter the water table through separate vadose zone modeling (McDowell-Boyer, 2000). Locations are typically identified through I, J, K grid indices referring to sequential numbering in the $\mathrm{x}-, \mathrm{y}-$, and $\mathrm{z}$-directions respectively. The present Special Study was initiated to better understand the differences between the slit trench Performance Assessment and Point Source Special Study, and determine the best approach for defining aquifer source nodes among various alternatives.

The present Special Study proposes an improvement to the current method for selecting aquifer source node locations that is a more realistic representation of actual subsurface conditions. This improved concept for defining aquifer source node locations has been identified through an objective evaluation of several alternatives. The recommended source node configuration has a 5 cell footprint compared to 6 cells in the PA. Vertically, the mass flux produced by the vadose model is placed in cells primarily within the upper Upper Three Runs (UTR) aquifer zone (vertical cell layers $\mathrm{K}>12$ ) in the alternative configuration, compared to placement in both the tan clay and lower UTR aquifer zones in the PA $(\mathrm{K} \leq 12)$. Peak concentrations at the 100 meter well can be expected to increase by a factor between approximately 2.5 and 3, at least for relatively conservative species such as I-129 and Tc-99. These expectations are limited to the E-Area Slit Trenches.

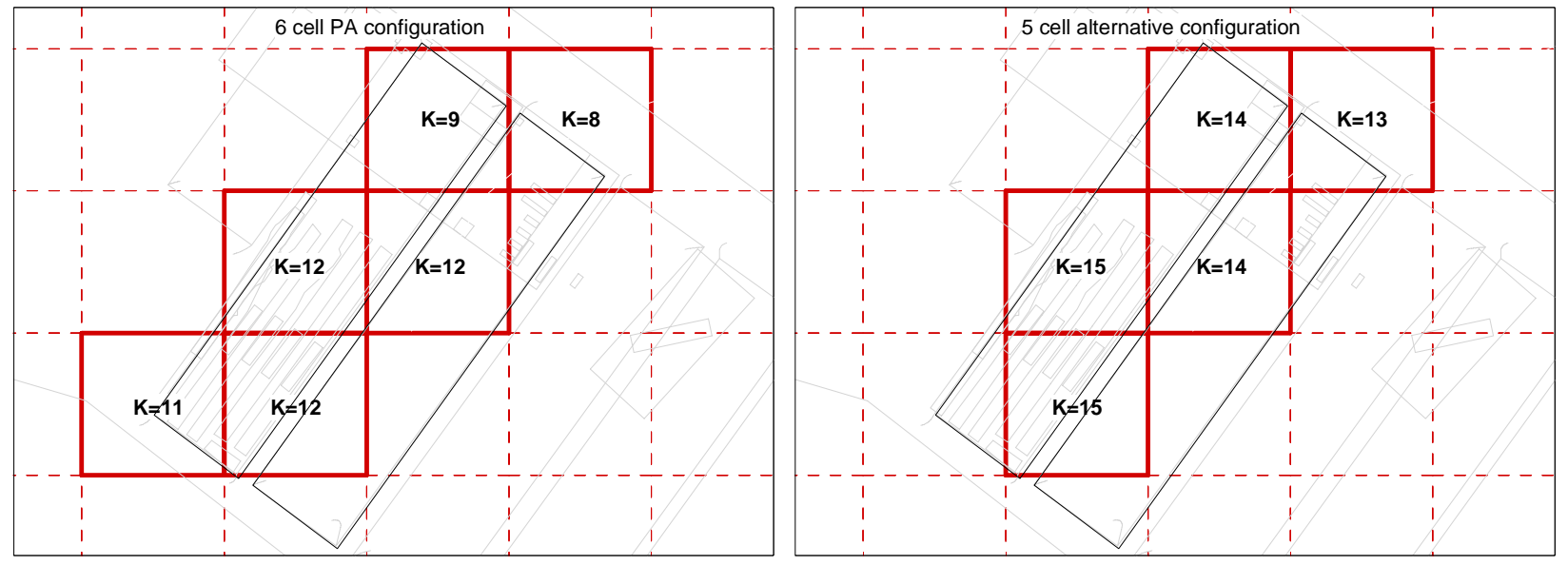


SRTC has recently proposed that interim measures be considered as part of an annual assessment of the analyses being performed each year under PA Maintenance (Butcher, 2003). The potential impact of this alternative representation should be considered when SRTC and SW Engineering perform their Interim Measures Assessment in April. To support this determination, additional modeling runs and further optimization will be performed to address radionuclides significantly contributing to the sum-of-fractions for trenches. The objective of this process is to minimize disruptions to Solid Waste Operations, in particular, to reduce the risk of exceeding allowable radionuclide inventory in a disposal unit due to a potential future change in limits. 


\section{Table of Contents}

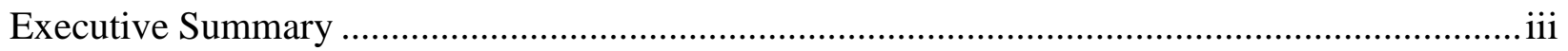

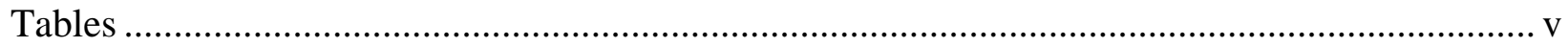

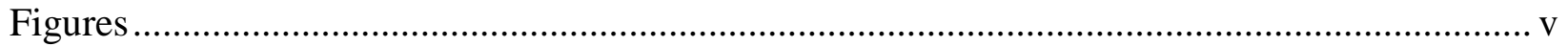

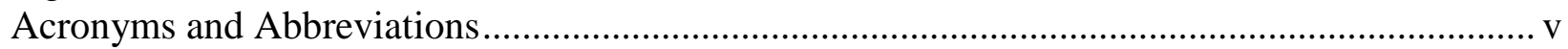

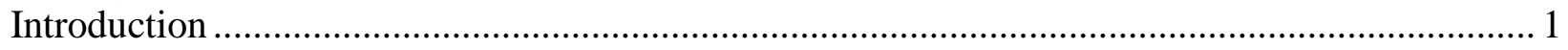

Criteria for Evaluating Alternative Source Node Locations ....................................................... 9

Alternative Configurations of Aquifer Source Nodes ................................................................... 9

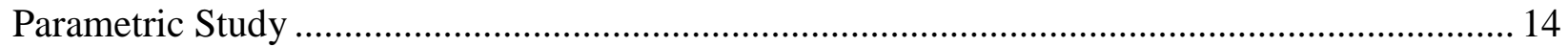

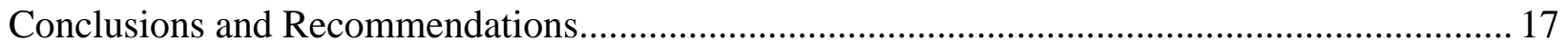

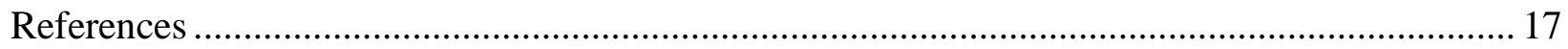

\section{Tables}

Table 1. Stratigraphy corresponding to aquifer cell layers ......................................................... 5

Table 2. Aquifer source nodes in the PA............................................................................... 6

Table 3. Criteria for evaluating source node location strategies .............................................. 9

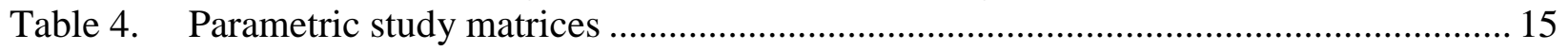

Table 5. Peak concentration results for I-129 and Tc-99 ……............................................... 16

\section{Figures}

Figure 1. Framework of E-Area Slit Trench PA modeling .................................................... 3

Figure 2. Vadose zone modeling ...................................................................................... 4

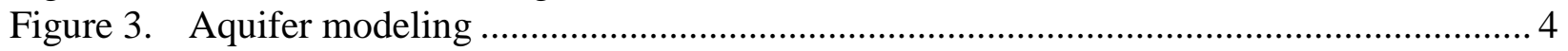

Figure 4. Mapping footprints of slit trenches to aquifer transport model cells ............................ 6

Figure 5. Computational grid for Point Source Special Study (reproduced from WSRC-TR-2002-00117) ..............................................................................

Figure 6. Comparison of PA and Point Source Special Study models; (a) plan view; (b) crosssectional view (reproduced from WSRC TR 2002 00117) .......................................... 8

Figure 7. Horizontal configurations of aquifer source nodes ...................................................... 12

Figure 8. Vertical configurations of aquifer source nodes ....................................................... 13

\begin{tabular}{|c|c|}
\hline \\
\hline \\
\hline \\
\hline \multicolumn{2}{|c|}{$\begin{array}{ll}\text { Acronyms and Abbreviations } \\
\text { LAW } & \text { low activity waste } \\
\text { PA } & \text { performance assessment } \\
\text { pCi/L } & \text { picocuries per liter }\end{array}$} \\
\hline \multicolumn{2}{|l|}{$\begin{array}{l}\text { UTh } \\
\text { VZ }\end{array}$} \\
\hline & dose zone \\
\hline \multicolumn{2}{|r|}{ water table } \\
\hline
\end{tabular}




\section{Introduction}

Waste acceptance criteria (WAC) for the E-Area Slit Trenches are based on a Performance Assessment (PA), comprised in part of model predictions of peak radionuclide concentration at a hypothetical 100 meter well (WSRC, 2002; McDowell-Boyer, 2000). Figure 1 illustrates the framework of the peak aquifer concentration analysis. Radionuclide migration from trenches to the 100 meter well is simulated in two stages: two-dimensional vadose zone transport from the trench to water table (Figure 2), and three-dimensional saturated zone transport from the water table beneath the trench to the 100 meter well (Figure 3). The PORFLOW code is used to simulate vadose zone flow and transport, and aquifer transport (Analytical \& Computational Research Inc., 2000). The FACT code is used to simulate aquifer flow (Hamm and Aleman, 2000).

A recent Special Study focusing on the potential impacts of non-uniform waste distribution in the E-Area Slit Trenches indicates that alternative strategies for defining aquifer model source node locations may significantly affect the peak concentration observed at the 100 meter well (Collard, 2002). To enable accurate representation of point sources and corresponding downstream effects in the Special Study, a re-oriented and finer resolution computational mesh was used to simulate aquifer flow and transport. When a uniform waste distribution was modeled as a precursor to various hypothetical point source scenarios, peak concentrations at the 100 meter well were on the order of 2 times higher than reported in the Performance Assessment for I-129 (McDowell-Boyer, 2000; Collard, 2002). A preliminary assessment suggested that differences in peak concentrations between the Special Study and PA models were primarily due to differences in aquifer model source node locations, as opposed to mesh resolution and orientation. The present Special Study was initiated to better understand the differences between the slit trench Performance Assessment and Point Source Special Study, and determine the best approach for defining aquifer source nodes among various alternatives.

Aquifer source nodes represent the centroid of grid blocks in the aquifer transport model where the contaminant flux simulated in the vadose zone modeling is introduced. The contaminant source is calculated beforehand as the transient mass flux crossing the water table, assumed to reside at the bottom boundary of the vadose zone model. The aquifer transport model simulates the movement of contaminant from the source cells to a 100 meter hypothetical well that is represented as a monitoring cell in the model. Therefore, selection of the location for aquifer source cells is important to predicting contaminant concentrations in groundwater that are used to calculate inventory limits for E-area slit trench disposal facilities. Because the aquifer model actually includes both the saturated and unsaturated zones, logic is needed to choose the appropriate vertical layer corresponding to the water table and bottom of the vadose model.

In the PA, two sets of slit trenches (five trenches per set) were simulated in the aquifer transport model. Each set of five slit trenches was assumed to have a footprint of $200 \mathrm{~m}$ by $48 \mathrm{~m}$ (656 ft by $157 \mathrm{ft}$ ) as shown in Figure 2.2-4 of the PA (McDowell-Boyer, et al., 2000). The PORFLOW aquifer transport model used a subset of the computational grid from the FACT aquifer flow model, with individual cells being $200 \mathrm{ft}$ by $200 \mathrm{ft}$ in both models $(61 \mathrm{~m}$ by $61 \mathrm{~m}$ ) (Flach and Harris, 1999). Vertically both aquifer models extend from the ground surface to the bottom of the Congaree Aquifer and are comprised of the same 20 grid cell layers. Various groups of grid layers represent the aquifer and confining zones and units beneath the General Separations Area 
as shown in Table 1. Note that FACT and PORFLOW use different indices to identify the same computational cell (Hamm and Aleman, 2000; Analytical \& Computational Research Inc., 2000).

The physical footprint comprising two sets of slit trenches was mapped to six columns of grid cells in the PA aquifer transport model as shown in Figure 4. The I and $\mathrm{J}$ indices refer to PORFLOW grid node numbers in the $\mathrm{x}$ - and $\mathrm{y}$-directions respectively. Vertical placement of the source within each column was based on the concept that the saturated zone beneath the water table can be defined as the first grid cell with $>99 \%$ saturation that is encountered during a top down search. Some later Special Analyses used a saturation level of at least $99.9 \%$ to define the first cell fully beneath the water table. The PA modeling identified six aquifer source cells at varying layers as shown in Table 2 . The $\mathrm{K}$ index refers to PORFLOW grid node numbers in the $\mathrm{z}$-direction. The vertical position of source nodes ranges from $\mathrm{K}=12$ to 8 . Referring to Table 1 , PORFLOW grid indices $K=11$ and 12 reside in the tan clay confining zone, and $K=8$ and 9 are in the lower UTR aquifer zone (Barnwell-McBean aquifer).

The Point Source Special Study (Collard, 2002) used local flow and transport models around the 2 sets of slit trenches, with boundary conditions taken from the PA aquifer flow model (Figure 5). The aquifer source and $100 \mathrm{~m}$ well cells defined in the PA and Point Source Special Study are compared in Figure 6. The aquifer source cells are approximately co-located in plan view, but separated in elevation, even though the same concept was used to define the saturated zone, i.e. $>99 \%$ saturation. Aquifer source nodes generally lie in the upper UTR aquifer in the Point Source study, and comprise a relatively continuous layer. In contrast, the PA source nodes are non-contiguous, split between the tan clay and lower UTR aquifer zones, and comprise thicker cells on average. Peak concentrations were roughly twice as high in the Special Study for the equivalent uniform waste distribution. The discrepancy in source node elevations and peak concentrations was noted in the Point Source Special Study, and provides motivation for the present "Source Node" Special Study.

The present Special Study is also a good opportunity to evaluate various alternative strategies for defining aquifer source nodes, within the framework of the present PA aquifer transport model. In the analysis that follows, several horizontal and vertical configurations of aquifer sources are considered in addition to the baseline PA configuration. For each configuration, objective performance criteria are used to evaluate merits, and peak concentrations at the $100 \mathrm{~m}$ well are computed for assessing impacts. Based on the pros and cons of each alternative, a preferred approach for defining aquifer source nodes is recommended for future Performance Assessments and Special Analyses. 


\section{PA modeling framework}

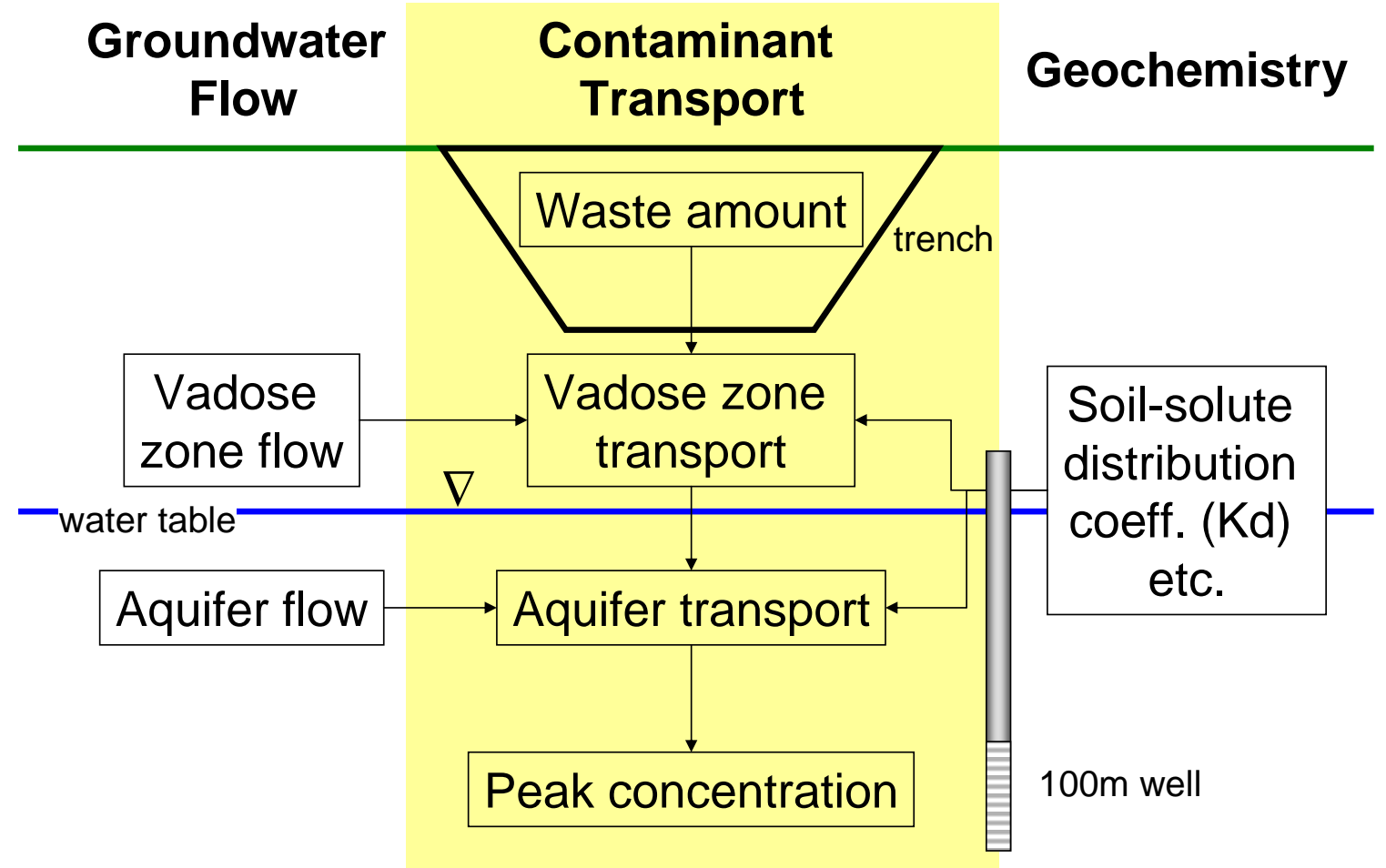

Figure 1. Framework of E-Area Slit Trench PA modeling. 


\section{Vadose zone models}

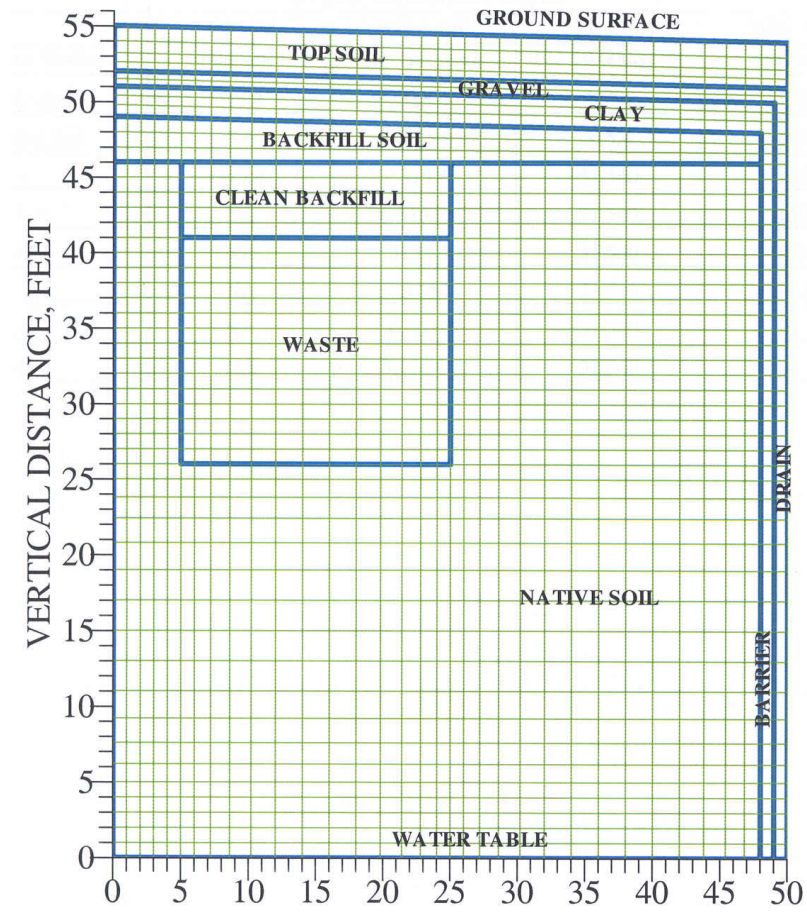

Representative

2D slice through

waste zone

from ground

to water table

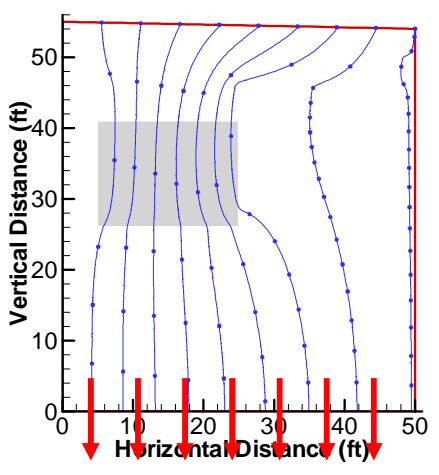

Contaminant flux

Figure 2. Vadose zone modeling.

\section{Aquifer models}

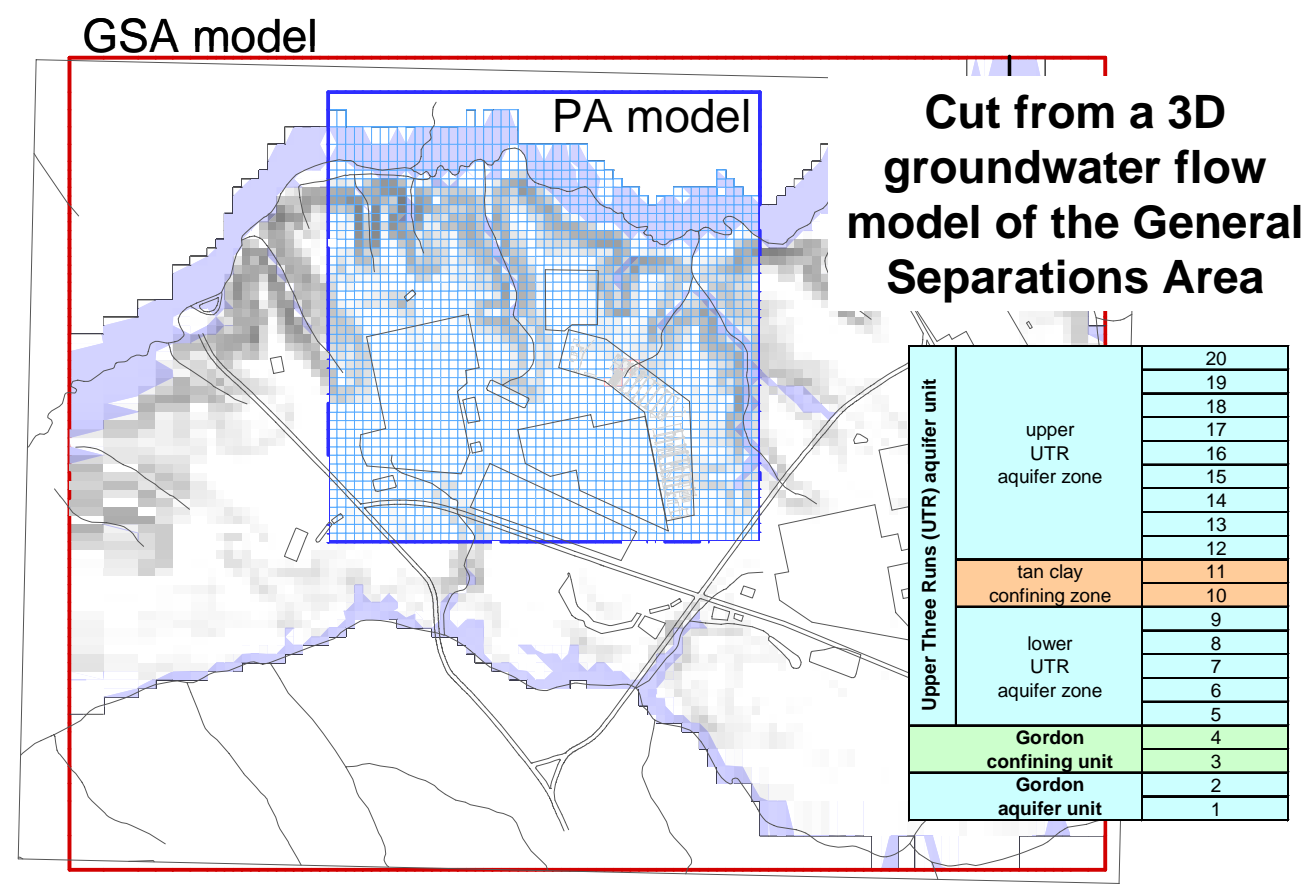

Figure 3. Aquifer modeling. 
Table 1. Stratigraphy corresponding to aquifer cell layers.

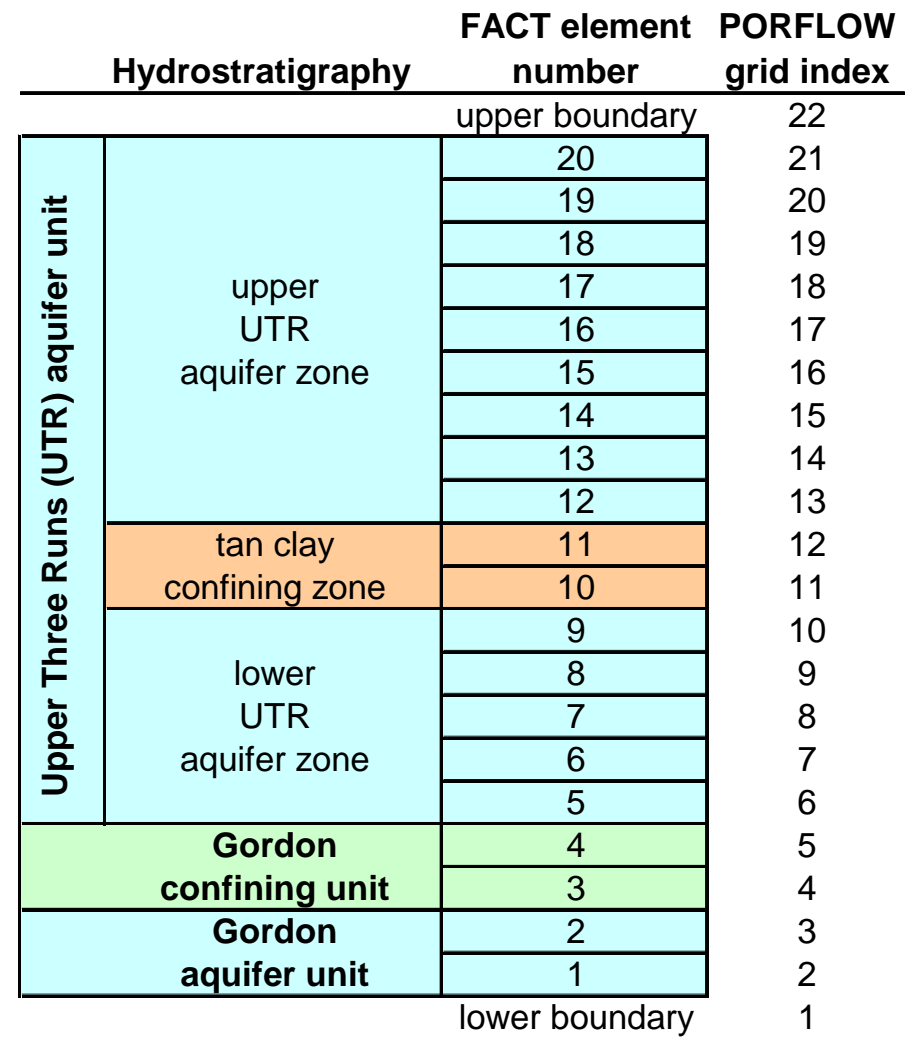




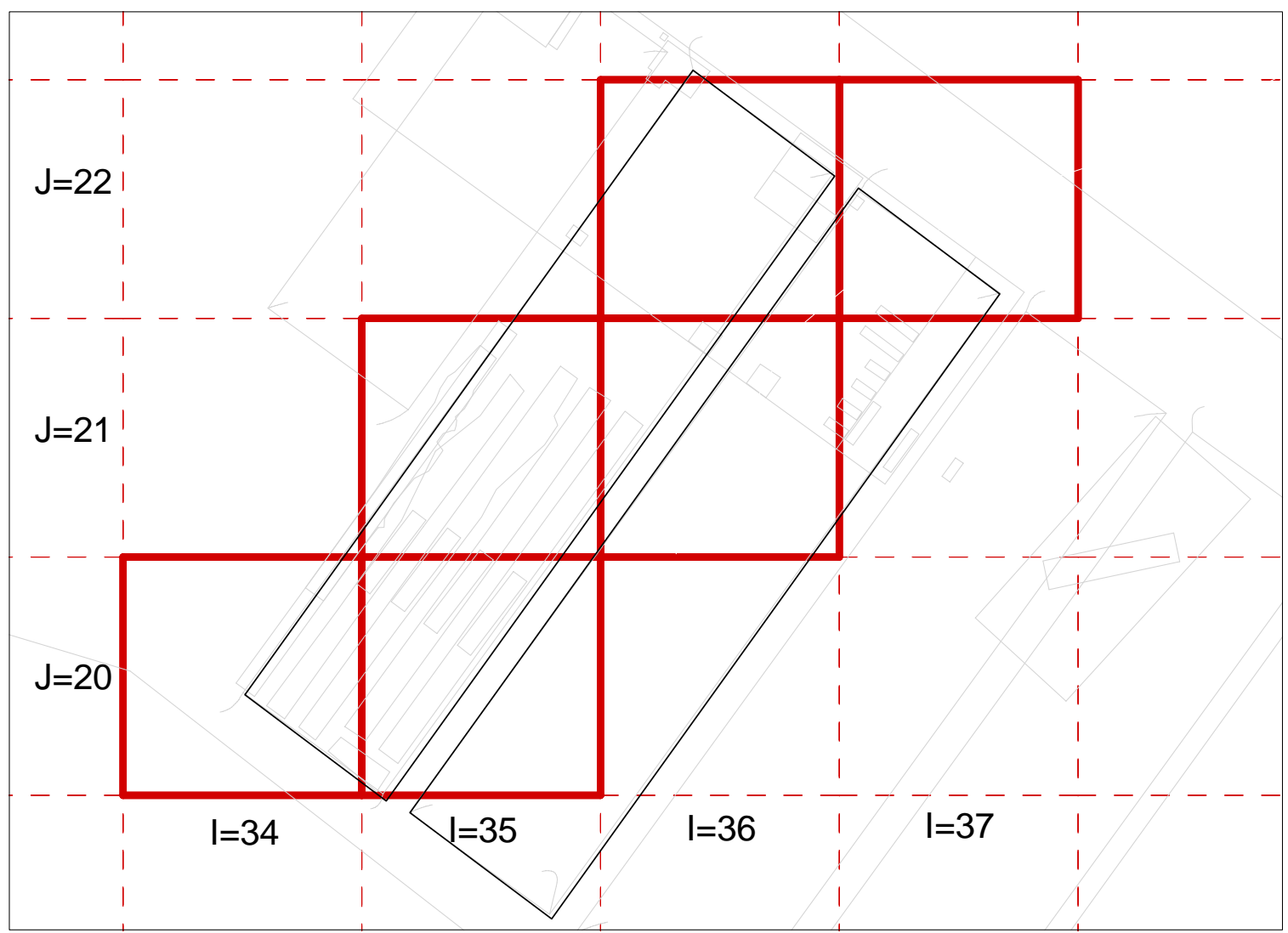

Figure 4. Mapping footprints of slit trenches to aquifer transport model cells.

Table 2. Aquifer source nodes in the PA.

\begin{tabular}{cccc}
\hline $\begin{array}{c}\text { Aquifer Source } \\
\text { Cell ID }\end{array}$ & I & PORFLOW Grid Indices & K \\
\hline 1 & 34 & J & 11 \\
2 & 35 & 20 & 12 \\
3 & 35 & 21 & 12 \\
4 & 36 & 21 & 12 \\
5 & 36 & 22 & 9 \\
6 & 37 & 22 & 8 \\
\hline
\end{tabular}




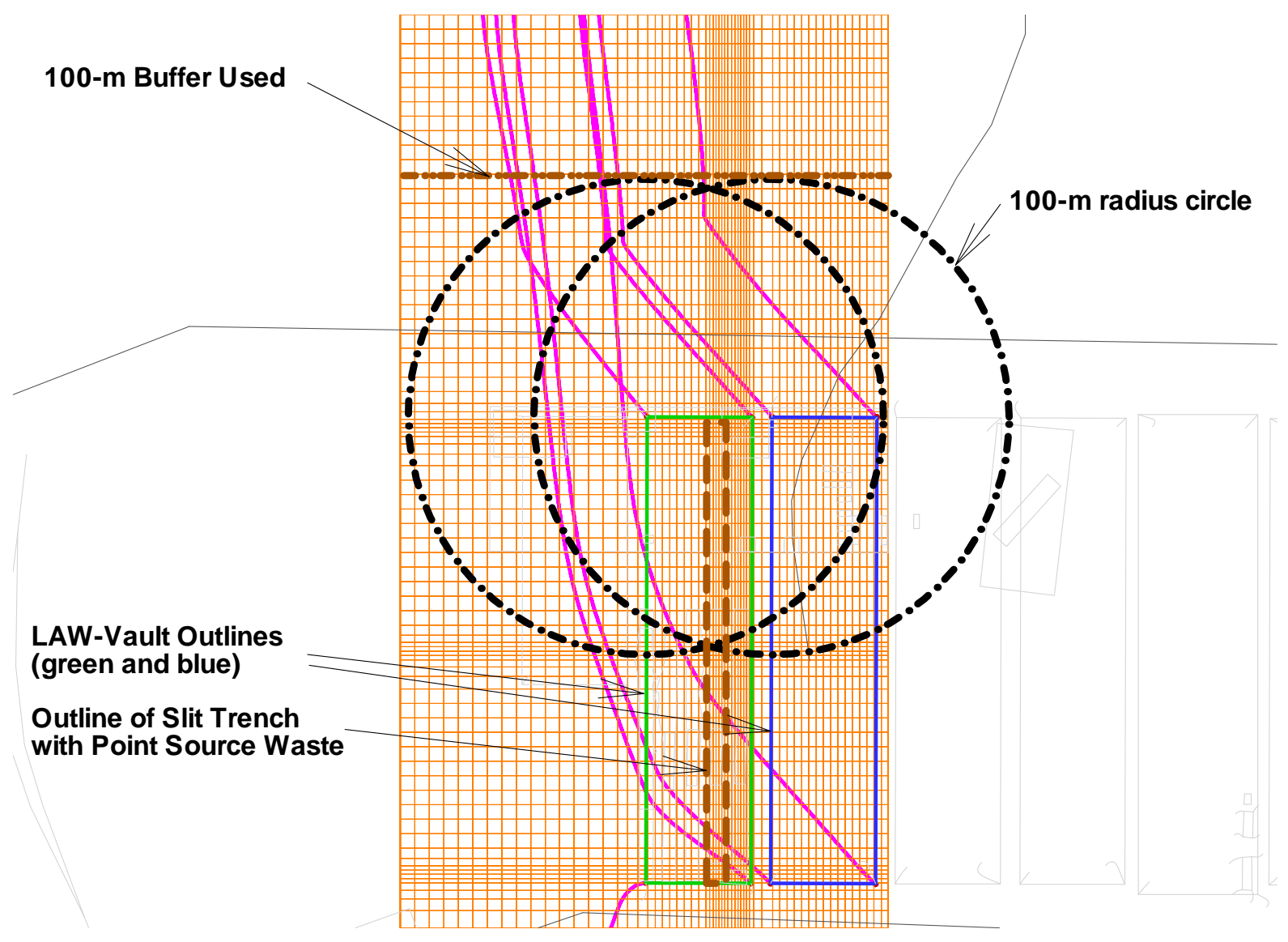

Figure 5. Computational grid for Point Source Special Study (reproduced from WSRC-TR-2002-00117). 


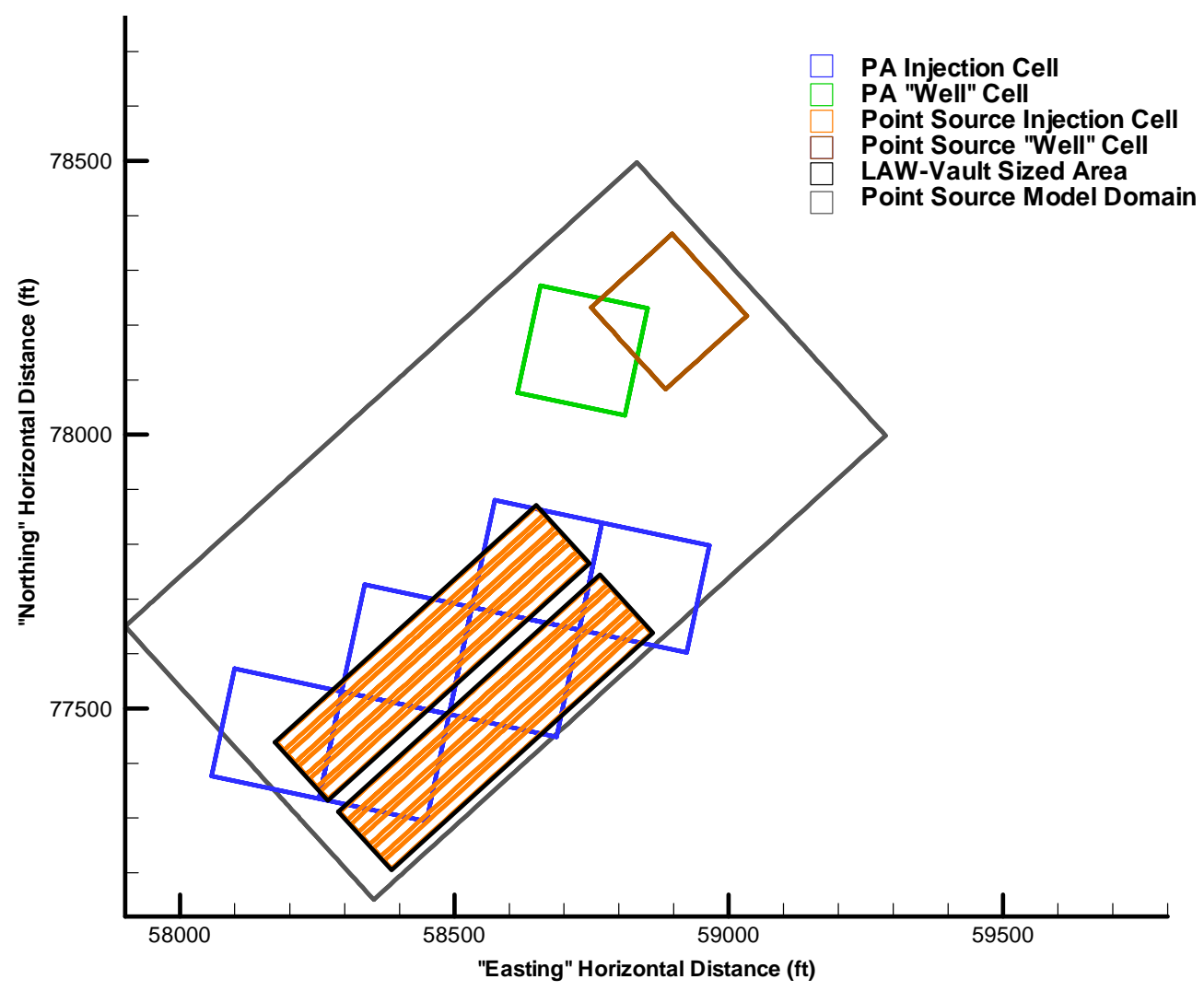

(a)
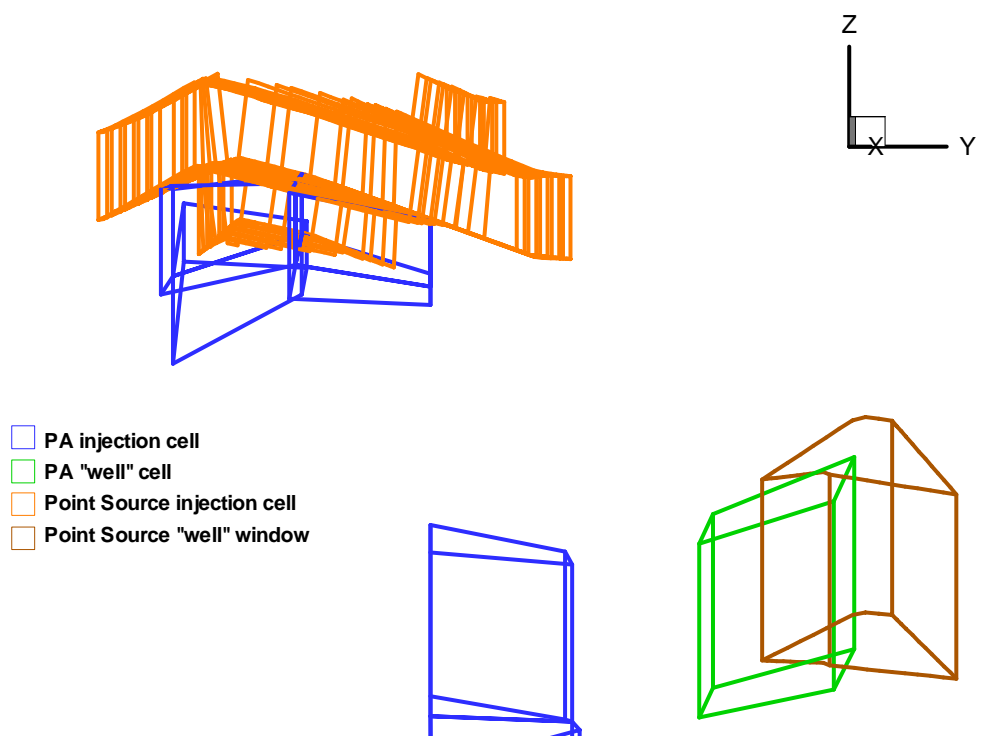

(b)

Figure 6. Comparison of PA and Point Source Special Study models; (a) plan view; (b) cross-sectional view (reproduced from WSRC-TR-2002-00117). 


\section{Criteria for Evaluating Alternative Source Node Locations}

Several criteria for assessing the merits of various source node location schemes are identified in the present Special Study, as summarized in Table 3. In plan view, the source zone as represented in the aquifer transport model should ideally preserve the location, area and shape of the physical source zone in the aquifer. With respect to elevation, the aquifer source nodes should ideally coincide with the bottom of the vadose model and the water table. The collection of source nodes should also form a contiguous zone, rather than contain artificial offsets due to coarse grid resolution. More generally, source nodes should reside in an aquifer zone, rather than a confining zone, following the concept that contaminant migration would occur primarily due to advection through higher permeability sediment. Also, the vertical thickness of source cells should be sufficiently thin to avoid excessive numerical dilution (McDowell-Boyer et al., 2000, p. 2-28). Finally, given that the above criteria can create competing factors, the source node configuration should ultimately produce best- or conservative-estimates of peak concentrations at a hypothetical 100 meter well.

Table 3. Criteria for evaluating source node location strategies.

Spatial attributes
1) Preserve location (centroid) of waste footprint
2) Preserve area of waste footprint
3) Preserve shape of waste footprint
4) Match elevation of vadose zone model bottom
5) Match water table elevation
6) Form a contiguous source zone in aquifer model
General attributes
7) Deposit in a permeable (not confining) zone
8) Deposit in a sufficiently thin grid cell (avoid numerical dilution)
9) Produce a best- or conservative-estimate

\section{Alternative Configurations of Aquifer Source Nodes}

In developing candidate alternative aquifer source node configurations, the grids of the vadose zone and aquifer numerical models was considered to be fixed in making these selections. Figure 7 displays the horizontal configurations considered for aquifer source nodes in the present study. The 6 cell configuration is that used in the PA. With respect to the criteria identified in Table 3, the centroids of the 4 and 6 cell alternatives are closest to the center of the combined LAW vault footprints. The 5 cell configurations match the physical area more closely. The slit trenches are oriented at an angle of approximately 45 degrees relative to grid lines, and none of the configurations reproduces the shape of the physical source zone particularly well. Nevertheless, the 6 cell option appears to better reproduce the aspect ratio of the actual slit trenches.

Hence, given the existing PA aquifer model grid, tradeoffs exist between competing objectives in Table 3. The orientation and grid block dimensions of the General Separations Area flow model (Figure 3) was optimized to match regional-scale physiographic features and groundwater flow simulation needs, and later applied to E-area Performance Assessment. A more accurate 
representation of the physical trenches could be achieved by refining and/or re-orienting the model grid, as was done in the Point Source Special Study for example. Modifications to the model grid was beyond the scope of this special study, but could be considered in subsequent Performance Assessments or Special Analyses.

The 5 cell configurations are preferred over the 4 and 6 cell configurations because area strongly affects concentration for a fixed mass flux from the vadose model. The larger discrepancy in location with the 5 cell options is not an important issue because the 100 meter well is defined to be 2 grid blocks away from an aquifer cell with the highest $\mathrm{J}$ index. Thus the distance between source and well in the model is fixed as a practical matter. Between the 5 cell alternatives, the downstream configuration is slightly preferred over the upstream case because the former is closer to the physical 100 meter well. Thus the 5 cell downstream alternative can be viewed as slightly more conservative than the 5 cell upstream case.

For each vertical column of cells depicted in Figure 7, a single grid cell is selected for depositing the mass flux leaving the bottom of the two-dimensional vadose zone model. Ideally, the selected cell will coincide with the bottom of the vadose zone model and contain the water table (Table 3). As the dimensions of the vadose zone model were fixed in the PA, and the depth to the water table varies across the two LAW vault footprints, matching both criteria is generally not possible however.

Figure 8 presents the 5 vertical configurations considered in the present study. The first configuration is the vertical source node assignments reported in the PA. The second configuration identifies the PORFLOW index of the first $100 \%$ saturated cell from top down. The third configuration places the contaminant flux at the water table. In the fourth scheme, the source nodes lie at approximately $46 \mathrm{ft}$ below ground, coinciding with the bottom of the vadose zone model, with one exception. At location $\mathrm{I}=37 \mathrm{~J}=22,46 \mathrm{ft}$ below ground is just inside layer $\mathrm{K}=12$ comprising a portion of the tan clay confining zone. To avoid violating criterion 7) in Table 3, and considering that $-46 \mathrm{ft}$ is only $1 \mathrm{ft}$ below the bottom of layer $\mathrm{K}=13$, the original location $(37,22,12)$ was replaced with $(37,22,13)$ in vertical configuration 4). The fifth alternative places all of the contamination in layer 14 for maximum continuity of the aquifer source zone (criterion 6). Although a 6 cell footprint is shown for each of the vertical configurations for completeness, the horizontal and vertical configurations can be independently selected and a pairing defines the aquifer source nodes in three dimensions. A total of 20 combinations are possible.

Although the PA was based on a slightly different criterion (>99\% saturation), the elevation differences between the "PA" and "100\% saturation" vertical configurations indicate an inconsistency in implementing the PA conceptual model for selecting the effective saturated zone. The water table configuration ("WT") is based on the concept that the vadose zone model defines the mass flux crossing the water table dividing the saturated and unsaturated zones. Therefore, the mass flux should arguably be placed in the grid cell containing the water table, rather than the underlying fully saturated cell. Because the vadose zone model was designed to extend to the average depth of water beneath the slit trenches, the "WT", "VZ model" and "Same layer" schemes produce similar but not identical elevations, with each satisfying one of criteria 4 through 6. All three schemes satisfy criteria 7 and 8 , in that the aquifer source lies in relatively thin sub-layers of the upper UTR aquifer zone. All are preferred over the "100\% saturation" and 
"PA" schemes, which do not precisely satisfy any of criteria 4 through 7 . The "VZ model" configuration is most consistent with the output of the vadose zone model, namely mass flux at a depth of $46 \mathrm{ft}$. For this reason, it might be slightly preferred over the "WT" and "Same layer" schemes.

A parametric study, described in the next section, is used for better understanding the impact of various horizontal and vertical aquifer source node configurations on peak aquifer concentrations. The location of the hypothetical 100 meter well producing the peak aquifer concentration can be expected to vary somewhat with source node configuration. Aquifer simulations performed under the parameter study must therefore include monitoring of a sufficiently large vertical "curtain" of grid cells. In the upcoming parameter study, the monitoring curtain extends from PORFLOW index $\mathrm{K}=9$ through 16 and encircles the downstream perimeter of the aquifer source zone at a separation distance of 2 grid cells (400 ft or approx. $100 \mathrm{~m})$.

In the PA, contamination is placed in individual cells on a per unit volume basis. An alternative method is a per unit area specification, on the basis that the vadose zone model defines a flux crossing a horizontal surface, whether that be the water table or bottom of the vadose zone model. Selecting between these two methods for introducing contamination creates an additional degree of freedom also considered in the parametric study.

In PA simulations, water saturation was set to $100 \%$ throughout the aquifer model for convenience. Because vertical configurations 4) and 5) contain source nodes at and/or above the water table representing partially saturated grid cells, unlike the PA simulations, water saturations computed in the vadose zone are more important to the overall simulation. Additional simulations testing the effect of variable saturation in the aquifer model are also considered in the parametric study to follow. 

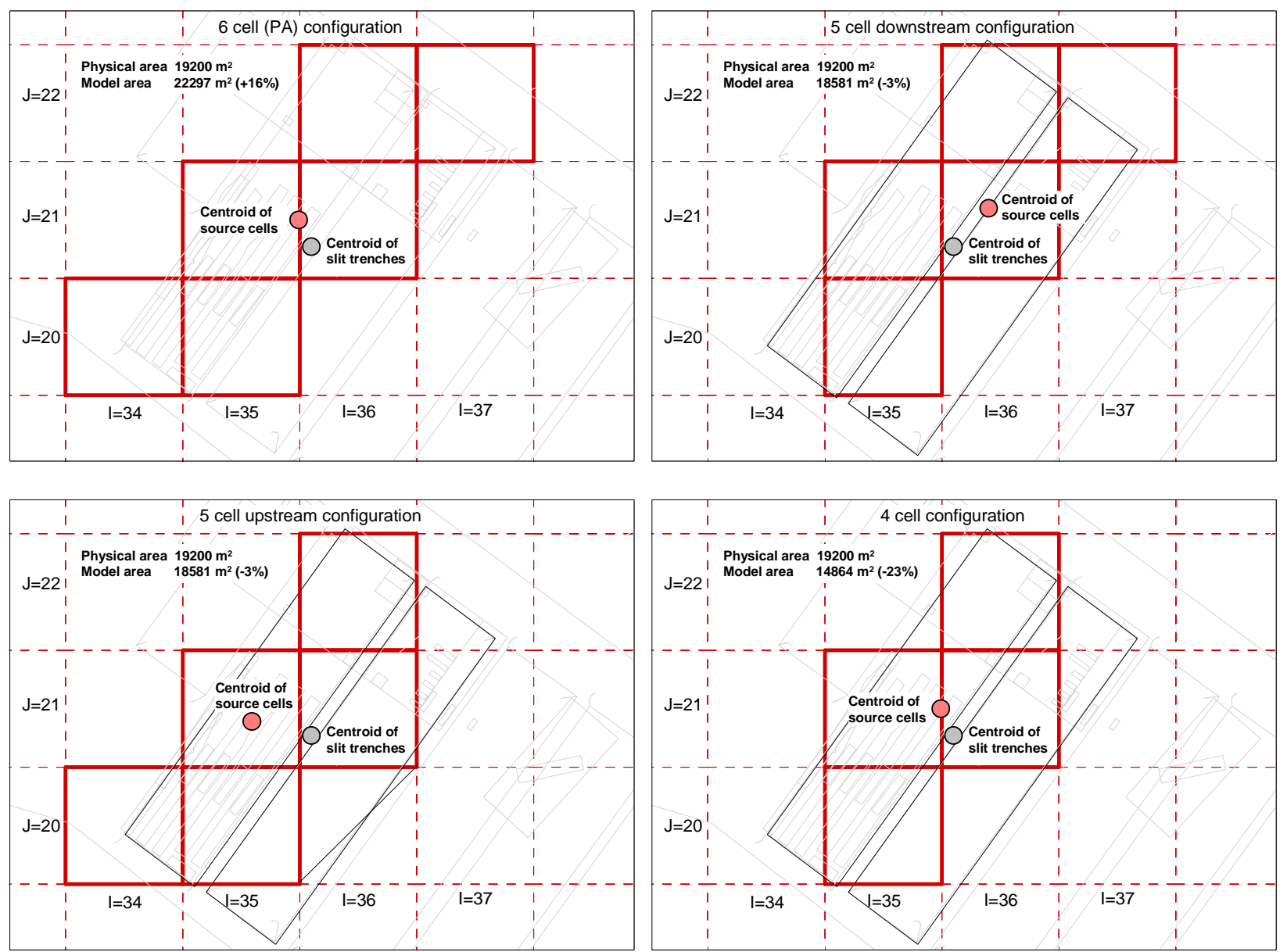

Figure 7. Horizontal configurations of aquifer source nodes. 
Horizontal configurations

(in terms of PORFLOW I,J)

1) 6 cell (PA)

$\begin{array}{llllll}J \backslash I & 34 & 35 & 36 & 37 & 38\end{array}$

23

22

21

20

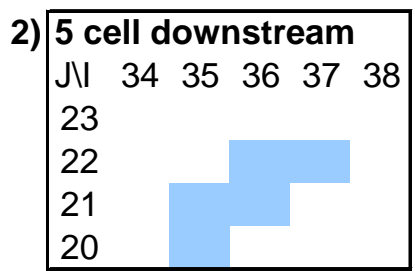

3) 5 cell upstream

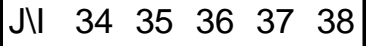

23

22

21

20

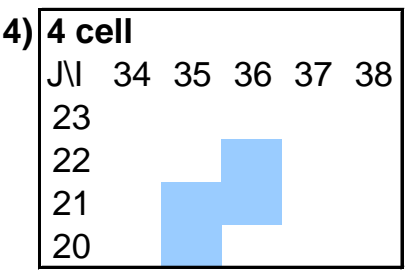

Vertical configurations

(in terms of PORFLOW K)

1) PA

$\begin{array}{llllll}J \backslash I & 34 & 35 & 36 & 37 & 38\end{array}$

23

22

$21 \quad 12 \quad 12$

$\begin{array}{lll}20 & 11 & 12\end{array}$

2) $100 \%$ saturation

$\begin{array}{llllll}J \backslash I & 34 & 35 & 36 & 37 & 38\end{array}$

23

22

21

$2012 \quad 12$

3) WT

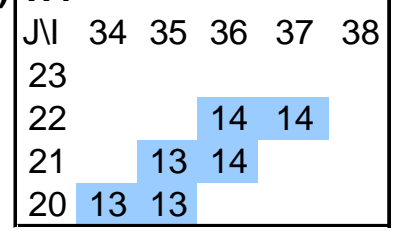

4) VZ model $^{*}$

$\begin{array}{llllll}J \backslash I & 34 & 35 & 36 & 37 & 38\end{array}$

23

22

21

$1413^{*}$

1514

$15 \quad 15$

5) Same layer

\begin{tabular}{|lllllll}
$J \backslash I$ & 34 & 35 & 36 & 37 & 38 \\
23 & & & & & \\
22 & & & 14 & 14 & \\
21 & & 14 & 14 & & \\
20 & 14 & 14 & & & \\
\hline
\end{tabular}

* original location $(37,22,12)$ changed to $(37,22,13)$ to avoid placing contamination in tan clay confining zone $(K=12)$

Figure 8. Vertical configurations of aquifer source nodes. 


\section{Parametric Study}

Given 4 horizontal configurations, 5 vertical configurations, and 2 source introduction modes (per unit volume versus per unit area), a total of 40 separate cases could be considered for each radionuclide in a parametric study. Table 4 identifies the subset of cases chosen for further evaluation. Case 4 corresponds to the PA. Case 8 is a more rigorous implementation of the PA conceptual definition of the saturated zone. The results from cases 5 through 8 define the variation in peak concentration with horizontal footprint using the revised implementation of the PA logic. Cases 8,12,16 and 20 define the variation with the vertical configuration of aquifer source nodes and a 6 cell footprint. The remaining per unit volume cases are centered about the 5 cell downstream horizontal configuration and the vadose zone ("VZ") model vertical configuration, which were collectively identified as the preferred aquifer source node specification scheme. Case $8 \mathrm{a}$ is designed to test the impact of a per unit area basis versus per unit volume.

Two radionuclides were considered for each source node case, I-129 and Tc-99. The waste zone soil-solute distribution coefficients $\left(K_{d}\right)$ for I-129 and Tc-99 in the PA are 0.6 and $0.36 \mathrm{ml} / \mathrm{g}$ respectively, so both species are relatively mobile. The radioactive half-lives are $1.72 \times 10^{7}$ years for I-129 and $2.11 \times 10^{5}$ years for Tc-99, and both species can be considered long-lived. These and other transport parameters from the PA simulations are held fixed in the present parametric study.

Peak concentrations simulated at a hypothetical 100 meter well are summarized in Table 5. For I-129, the peak concentration for Case 4 computed in the present Special Study is essentially the same as reported in the PA. For Tc-99, the peak concentration for Case 4 is $20 \%$ larger. The discrepancy is apparently a result of the time history for Tc-99 being recorded at 10 year increments in the PA compared to 1 year increments in the present study. The peak concentration occurs at 24 years for Case 4, while concentrations were recorded at 20 and 30 years of elapsed time in the PA (cf. McDowell-Boyer et al., 2000, Figure G-38). The time of peak concentration occurs earlier for Tc-99 compared to I-129 because the species is less retarded (lower $K_{d}$ ).

Revising implementation of the PA conceptual definition of the saturated zone produces a factor of about 2.0 increase in the peak concentration (Case 8 compared to Case 4). Note that the vertical location of the 100 meter well varies somewhat with source node locations, but the horizontal location is unchanged. Reducing the footprint from 6 cells to 5 or 4 cells increases peak concentration as expected, roughly in proportional to the area reduction (Cases $8 \rightarrow 7 \rightarrow 6$ $\rightarrow 5$ ). Alternative schemes for defining the elevation of source nodes produced a smaller effect on the order of 10-20\% (Cases 8, 12, 16 and 20). The preferred source node configuration, Case 14 , results in a peak concentration that is 2.6 times higher than the PA for I-129, and 3.0 times higher for Tc-99. Introducing contaminant mass on a per unit area basis produced little change (Case 8a compared to Case 8). Using variable saturations, as simulated by the FACT aquifer flow model, produces slightly higher peak concentrations and earlier arrival (Cases 10b and 14b compared to Cases 10 and 14 respectively).

The horizontal location of the peak aquifer concentration node is the same for all cases, but the elevation varies with average elevation of aquifer source nodes. For vertical configurations 2) through 5), the peak concentration occurs in layer 11 or 12, which lies just above the layer 
containing the water table at that horizontal location. Apparently, significant lateral contaminant migration is occurring in the capillary fringe adjacent to the water table surface. This effect is believed to be an artifact of an excessively thick capillary fringe in the FACT groundwater flow model, and should be further investigated.

Table 4. Parametric study matrices.

Baseline parametric study of source node configurations:

\begin{tabular}{|c|c|c|c|c|}
\hline$v l h$ configuration & 4 cell & $\begin{array}{c}5 \text { cell } \\
\text { downstream }\end{array}$ & $\begin{array}{c}5 \text { cell } \\
\text { upstream }\end{array}$ & $\begin{array}{l}(P A) \\
6 \text { cell }\end{array}$ \\
\hline$P A$ & case 1 & case 2 & case 3 & case 4 \\
\hline $100 \%$ saturation & case 5 & case 6 & case 7 & case 8 \\
\hline$W T$ & case 9 & case 10 & case 11 & case 12 \\
\hline VZ model & case 13 & case 14 & case 15 & case 16 \\
\hline Same layer & case 17 & case 18 & case 19 & case 20 \\
\hline
\end{tabular}

Per unit area, rather than volume, flux specification:

\begin{tabular}{|r|cccc|}
\hline vlh configuration & 4 cell & $\begin{array}{c}5 \text { cell } \\
\text { downstream }\end{array}$ & $\begin{array}{c}5 \text { cell } \\
\text { upstream }\end{array}$ & $\begin{array}{l}(P A) \\
6 \text { cell }\end{array}$ \\
\hline$P A$ & case $1 \mathrm{a}$ & case $2 \mathrm{a}$ & case $3 \mathrm{a}$ & case $4 \mathrm{a}$ \\
$100 \%$ saturation & case $5 \mathrm{a}$ & case $6 \mathrm{a}$ & case $7 \mathrm{a}$ & case $8 \mathrm{a}$ \\
$W T$ & case $9 \mathrm{a}$ & case $10 \mathrm{a}$ & case $11 \mathrm{a}$ & case $12 \mathrm{a}$ \\
$V Z$ model & case $13 \mathrm{a}$ & case $14 \mathrm{a}$ & case $15 \mathrm{a}$ & case $16 \mathrm{a}$ \\
Same layer & case $17 \mathrm{a}$ & case $18 \mathrm{a}$ & case $19 \mathrm{a}$ & case $20 \mathrm{a}$ \\
\hline
\end{tabular}

Variable, rather than $100 \%$, saturation in aquifer model:

\begin{tabular}{|r|cccc|}
\hline \multirow{2}{*}{ Vlh configuration } & 4 cell & $\begin{array}{c}5 \text { cell } \\
\text { downstream }\end{array}$ & $\begin{array}{c}5 \text { cell } \\
\text { upstream }\end{array}$ & $\begin{array}{c}(P A) \\
6 \text { cell }\end{array}$ \\
\hline$P A$ & case $1 \mathrm{~b}$ & case $2 \mathrm{~b}$ & case $3 \mathrm{~b}$ & case $4 \mathrm{~b}$ \\
$100 \%$ saturation & case $5 \mathrm{~b}$ & case $6 \mathrm{~b}$ & case $7 \mathrm{~b}$ & case $8 \mathrm{~b}$ \\
$W T$ & case $9 \mathrm{~b}$ & case $10 \mathrm{~b}$ & case $11 \mathrm{~b}$ & case $12 \mathrm{~b}$ \\
$V Z$ model & case $13 \mathrm{~b}$ & case $14 \mathrm{~b}$ & case $15 \mathrm{~b}$ & case $16 \mathrm{~b}$ \\
Same layer & case $17 \mathrm{~b}$ & case $18 \mathrm{~b}$ & case $19 \mathrm{~b}$ & case $20 \mathrm{~b}$ \\
\hline
\end{tabular}

Peak concentration results are generated for the bold cases. 
Table 5. Peak concentration results for I-129 and Tc-99.

l-129
\begin{tabular}{|c|ccc|c|c|c|c|}
\hline Case & $\begin{array}{c}\text { Peak conc. node } \\
\text { I }\end{array}$ & J & $\begin{array}{c}\text { Peak time } \\
\text { (yrs) }\end{array}$ & $\begin{array}{c}\text { Peak conc } \\
\text { (pCi/L) }\end{array}$ & $\begin{array}{c}\text { Conc } \\
\text { ratiot }\end{array}$ & $\begin{array}{c}\text { Conc } \\
\text { ratio2 }^{*}\end{array}$ \\
\hline PA & 36 & 24 & 9 & 29 & 477 & 1.0 & - \\
Case04 & 36 & 24 & 9 & 29 & 470 & - & 1.0 \\
\hline Case05 & 36 & 24 & 11 & 30 & 1291 & 2.7 & 2.7 \\
Case06 & 36 & 24 & 11 & 30 & 1118 & 2.4 & 2.3 \\
Case07 & 36 & 24 & 11 & 30 & 1066 & 2.3 & 2.2 \\
Case08 & 36 & 24 & 11 & 30 & 951 & 2.0 & 2.0 \\
Case10 & 36 & 24 & 12 & 31 & 1283 & 2.7 & 2.7 \\
Case12 & 36 & 24 & 12 & 31 & 1034 & 2.2 & 2.2 \\
Case13 & 36 & 24 & 12 & 31 & 1440 & 3.1 & 3.0 \\
Case14 & 36 & 24 & 12 & 31 & 1258 & 2.7 & 2.6 \\
Case15 & 36 & 24 & 12 & 31 & 1119 & 2.4 & 2.3 \\
Case16 & 36 & 24 & 12 & 31 & 1014 & 2.2 & 2.1 \\
Case18 & 36 & 24 & 12 & 31 & 1297 & 2.8 & 2.7 \\
Case20 & 36 & 24 & 12 & 31 & 1046 & 2.2 & 2.2 \\
Case8a & 36 & 24 & 11 & 30 & 898 & 1.9 & 1.9 \\
Case10b & 36 & 24 & 12 & 30 & 1333 & 2.8 & 2.8 \\
Case14b & 36 & 24 & 12 & 30 & 1324 & 2.8 & 2.8 \\
\hline
\end{tabular}

Tc-99

\begin{tabular}{|c|ccc|c|c|c|c|}
\hline Case & \multicolumn{2}{|c|}{$\begin{array}{c}\text { Peak conc. node } \\
\mathrm{I}\end{array} \mathrm{J}$} & $\mathrm{K}$ & $\begin{array}{c}\text { Peak time } \\
\text { (yrs) }\end{array}$ & $\begin{array}{c}\text { Peak conc } \\
\text { (pCi/L) }\end{array}$ & $\begin{array}{c}\text { Conc } \\
\text { ratiot }\end{array}$ & $\begin{array}{c}\text { Conc } \\
\text { ratio2 }^{*}\end{array}$ \\
\hline PA & 36 & 24 & 9 & 20 & 732 & 0.9 & - \\
Case04 & 36 & 24 & 9 & 24 & 852 & - & 1.2 \\
\hline Case05 & 36 & 24 & 11 & 24 & 2240 & 2.6 & 3.1 \\
Case06 & 36 & 24 & 11 & 24 & 1943 & 2.3 & 2.7 \\
Case07 & 36 & 24 & 11 & 24 & 1850 & 2.2 & 2.5 \\
Case08 & 36 & 24 & 11 & 24 & 1653 & 1.9 & 2.3 \\
Case10 & 36 & 24 & 12 & 24 & 2222 & 2.6 & 3.0 \\
Case12 & 36 & 24 & 12 & 24 & 1792 & 2.1 & 2.4 \\
Case13 & 36 & 24 & 12 & 24 & 2520 & 3.0 & 3.4 \\
Case14 & 36 & 24 & 12 & 24 & 2200 & 2.6 & 3.0 \\
Case15 & 36 & 24 & 12 & 24 & 1960 & 2.3 & 2.7 \\
Case16 & 36 & 24 & 12 & 24 & 1774 & 2.1 & 2.4 \\
Case18 & 36 & 24 & 12 & 24 & 2258 & 2.7 & 3.1 \\
Case20 & 36 & 24 & 12 & 24 & 1821 & 2.1 & 2.5 \\
Case8a & 36 & 24 & 11 & 24 & 1562 & 1.8 & 2.1 \\
Case10b & 36 & 24 & 12 & 23 & 2271 & 2.7 & 3.1 \\
Case14b & 36 & 24 & 12 & 23 & 2275 & 2.7 & 3.1 \\
\hline
\end{tabular}

† ratio of peak concentration computed in the present Special Study to the peak flux for Case04

* ratio of peak concentration computed in the present Special Study to the peak flux reported in the PA 


\section{Conclusions and Recommendations}

The present Special Study proposes an improvement to the current method for selecting aquifer source node locations that is a more realistic representation of actual subsurface conditions. This improved concept for defining aquifer source node locations has been identified through an objective evaluation of several alternatives. The recommended source node configuration has a 5 cell footprint compared to 6 cells in the PA. Vertically, the mass flux from the vadose model is placed in cells primarily within the upper UTR aquifer zone (PORFLOW grid index K > 12) in the alternative configuration, compared to placement in both the tan clay and lower UTR aquifer zones in the PA $(K \leq 12)$. Peak concentrations at the 100 meter well can be expected to increase by a factor between approximately 2.5 and 3 . These expectations are limited to the E-Area Slit Trenches.

Alternatively, multiple two-dimensional vadose zone models with varying depth to the water table, or a combined three-dimensional vadose and saturated zone model, could be used to define an aquifer source coinciding with the water table at all locations beneath the waste footprint. Other modifications that could be considered include refining and/or re-orienting the aquifer model grid to better represent the physical trenches. In any case, care should be taken to monitor likely peak well nodes with sufficient frequency to capture the peak concentration to within a few percent of the true peak. In the case of mobile species such as I-129 and Tc-99, the period should be one year or less.

SRTC has recently proposed that interim measures be considered as part of an annual assessment of the analyses being performed each year under PA Maintenance (Butcher, 2003). The potential impact of the recommended alternative representation should be considered when SRTC and SW Engineering perform their Interim Measures Assessment in April. To support this determination, additional modeling runs and further optimization will be performed to address radionuclides significantly contributing to the sum-of-fractions for trenches. The objective of this process is to minimize disruptions to Solid Waste Operations, in particular, to reduce the risk of exceeding allowable radionuclide inventory in a disposal unit due to a potential future change in limits.

\section{References}

Analytical \& Computational Research, Inc. 2000. PORFLOW User's Manual, Version 4.00, April.

Butcher, B. T. and E. L. Wilhite. 2003. E-Area Low-Level Waste Facility Performance Assessment Position Paper: History of Performance Assessment Methodology Development and Systematic Approach to Implementing Baseline Changes, WSRC-RP-2003-00303, Rev. 0, Westinghouse Savannah River Company, Aiken, South Carolina, 29808, March.

Collard, L.B. 2002. Effects of Point Sources in Slit Trenches at the E-Area Low-Level Waste Facility on Groundwater Concentrations, WSRC-TR-2002-00117, Rev. 0, Westinghouse Savannah River Company, Aiken, South Carolina, 29808, February. 
Flach, G.P., and M. K. Harris. 1999. Integrated hydrogeological modeling of the General Separations Area; Volume 2; Groundwater Flow Model (U), WSRC-TR-96-0399, Rev. 1, Westinghouse Savannah River Company, Aiken, South Carolina, 29808, April.

Hamm, L.L., and S. E. Aleman. 2000. FACT (Version 2.0); Subsurface Flow and Contaminant Transport Documentation and User's Guide, WSRC-TR-99-00282, Rev. 0, Westinghouse Savannah River Company, Aiken, South Carolina, 29808, March.

McDowell-Boyer, L., A.D. Yu, J.R. Cook, D.C. Kocher, E.L. Wilhite, H. Holmes-Burns, and K.E. Young. 2000. Radiological Performance Assessment for the E-Area Low Level Waste Facility, WSRC-RP-94-218, Revision 1, Westinghouse Savannah River Company, Aiken, South Carolina, 29808, January.

WSRC. 2002. WSRC IS Savannah River Site Waste Acceptance Criteria Manual, Procedure WAC 3.17 Low Level Radioactive Waste Acceptance Criteria, Rev. 7, September 16. 